\title{
Evaluation of CSR Performance of Sudanese Telecommunication Companies: A Case Study
}

\author{
Ahmed Zain Elabdin Ahmed \\ College of Business Administration, AUST-Fujairah Campus, Fujairah, UAE
}

\begin{abstract}
Corporate social responsibility (CSR) has received a lot of attention in the last few decades, from the economic responsibility to generate profits, to the discretionary responsibility to meet extra activities that society finds desirable. Companies are under pressure from the stakeholders to engage in the line of social, environmental, and economical responsibilities. Until now, no research has been conducted on CSR performance using a dataset from the telecommunication industry in Sudan. Hence, this paper has investigated the strategic importance of CSR in a Sudan telecommunication company (Sudatel). In doing so, the paper has sought to understand whether the concept of CSR programs is featured in the company's culture and strategic plans or whether the management of the company is highly committed to CSR programs. Telecommunication companies are expanding in economic size. Considered as the largest industry in the world in terms of employment and the fastest growing area in business, there are many social and economic benefits and opportunities that can be created through investment in the telecommunication infrastructure, which has the potential to enhance sustainable development, especially for developing countries. To investigate this problem, a qualitative case study methodology is used to collect and analyze the data. Results indicate that the CSR concept is part of the company's strategic plan and given high commitment from the top management.
\end{abstract}

Keywords: corporate social responsibility (CSR), telecommunication industry, Sudatel Company, Sudan

\section{Introduction}

Business organizations have recognized that to face the challenges in the competitive business environment, new approaches of management concepts are required.

In the last few decades, the pressure toward the role of companies in serving the society in which they exist has increased.

In the current competitive global environment, the awareness of the importance of corporate social responsibility (CSR) has been increased and recognized as a strategic tool that enables firms to gain a competitive advantage (Drucker, 1984).

Many benefits have been realized by adopting CSRs by companies, such as improving reputation, trust, risk management, and community relationships (Herrmann, 2004). Understanding the importance of CSR, this study has examined the strategic role of CSR in Sudan using Sudatel as a case, in which no research has been conducted, and much of CSR research originated from contexts of the developed markets (Luken, 2006).

Ahmed Zain Elabdin Ahmed, Ph.D., College of Business Administration, AUST-Fujairah Campus, Fujairah, UAE.

Correspondence concerning this article should be addressed to Ahmed Zain Elabdin Ahmed, AUST-CBA-Fujairah Campus, P.O. Box 2202, Fujairah, UAE. 
Hence, the main objective of this paper is to investigate the concepts of CSR in one of the leading telecom companies in Sudan. Sudatel Telecom Group (STG) is the first Sudanese company in the telecommunication industry. Since the foundation, STG has paid more than 36 million dollars for social responsibility activities to cover the needs in education, health, and water projects (Retrieved from www.sudatel.sd/en/Sudatel/section/?Topic=5182). This is the main reason why this study has selected STG to understand the drivers behind CSR plans used by the company.

\section{Literature Review}

CSR is regarded as one of the most dynamic perspectives that have received large controversy about its importance to business. Although a study by Friedman (1970) challenged the effectiveness of CSR, a recent study (Tiago \& Garrido-Morgado, 2012) has proposed that CSR is a key driver for corporate reputation.

There is no agreement on the definition of CSR. There are a large number of different proposals of definitions of social responsibility (Carmen, 2005). Despite the numerous efforts to bring about a clear and unbiased definition of CSR, there are some confusions as to how CSR should be defined (Alexander, 2008).

The confusion toward CSR comes from the two extremes of its definition: One defined by Mc Williams and Siegel (2001), which is very narrow, stated that actions appear to further some social good, beyond the interests of the firm and which required by law; and the other, the broad definition proposed by Van Marrewijk (2003), stated that in general, corporate sustainability and CSR refer to company activities voluntary by demonstrating the inclusion of social and environmental concerns in business operation and in interactions. Alexander (2008) identified five dimensions that reflect the definitions of CSR. Table 1 shows the five dimensions and example phrases referring to CSR.

Table 1

CSR Five Dimensions

\begin{tabular}{|l|l|}
\hline Dimensions & Example phrases \\
\hline The environmental dimension & A cleaner environment \\
\hline The social dimension & Contribute to better society \\
\hline The economic dimension & Contribute to the economic development \\
\hline The stakeholders dimension & Interaction with their stakeholders \\
\hline The voluntariness dimension & Based on ethical values \\
\hline
\end{tabular}

The perception toward CSR has several impacts on managerial decision making according to the countries status, such as developed or developing or advanced countries. Gjølberg (2009) argued that the country of origin matters to companies' CSR practices. Thus, there is a high likelihood that the differences would become even more pronounced if they were to compare from less developed countries.

In their article, Dobers and Halme (2009) concluded that this observation still raises an interesting question about the capacity of CSR contributions for developing and solving some pressing problems in the neediest part of the globe. While, the benefits behind CSR in developing countries are still limited in terms of human development (Kevin \& Jean, 2013); however, the impact differs according to the strategy of implementation.

The study conducted on the "influence of national context on CSR implementation" by Patsy (2012) selected seven export garment manufacturers of varying size and business model in Sri Lanka. It was found that harnessing the local cultural context can support the progress of CSR implementation at the factory level in Sri 
Lanka, the Buddhist philosophy provided by moral underpinning, and hence facilitated supplier engagement with CSR implementation.

The studies on developed countries (Mia \& Nakib, 2013) argued that implementing the CSR principles in the EU and the USA demonstrates that companies in the developed countries use a mix of different strategies to incorporate CSR principles into their self-regulatory mechanisms. They concluded that strategies based on legal regulation are not foremost in this mix, rather in these countries, regulation-based strategies are meant to assist the non-legal drivers of CSR, although, the practice and implementation in other countries, such as Republic of Korea, may take different forms affected by the governmental regulatory legislations and policy. Lee and Kim (2014) found that governmental legislation and incentives can play an important role in CSR implementation and practice and they added that CSR practice is not static but is dynamic, with regulatory legislations and norms.

It has been argued by Kloppers (2013) that the governments are regarded as some of the most important driving forces behind the CSR agenda and as a result have a particularly important role to play in the creation of an enabling CSR environment, but there is no agreement among researchers on the drivers behind the CSR, for example, De Jongh (2009) mentioned that the environment and concern about global climate change are now in the top of the list of corporate citizenship issues in all nations. Countries share concern over a number of other issues, such as product safety and working conditions. Breitbarth, Hovemann, and Walzel (2011) summarized the business drivers behind the CSR in Table 2.

Table 2

Business Drivers Behind CSR

\begin{tabular}{|l|}
\hline Improve image, reputation, and brand value \\
\hline Risk management \\
\hline Resource efficiency \\
\hline Access to financial capital \\
\hline Improve employee motivation and attractiveness as employer \\
\hline Innovation, "new way of thinking" \\
\hline Access to new markets \\
\hline Counter political, legislative, and regulatory pressure \\
\hline Build trust and legitimization \\
\hline Relationship building/maintenance with stakeholder and partner \\
\hline Passion organizational value and culture \\
\hline
\end{tabular}

Source: Breitbarth et al. (2011).

The perspective of managers toward CSR takes different forms. On one hand, Jamai and Sidani (2008) differentiated between two broad perspectives, the classical perspective that considers CSR as a burden on competitiveness and the modern perspective that views CSR as instrumental for business success; while on the other hand, Muller (2006) stated that perspectives differ based on multinational enterprises (MNEs), global CSR, or local CSR. Global CSR practice involves an efficient transmission through the organization worldwide, whereas local CSR perspective could be fragmented according to each country's CSR standard.

Other debate on mangers' perspectives toward CSR focuses on the role of socially responsible managers, i.e., it should help in establishing CSR rules. Globerman (2011) argued that socially responsible managers should participate in setting the rules of the games by advising policy makers on how specific regulations and 
laws can be structured, so that they most effectively condition the linkage between social objectives and profit maximization.

In contrast, other researchers have other views about CSR perspectives. In their study on CSR and access to finance, Beiting, Loannou, and Serafeim (2014) investigated whether superior performance on CSR strategies leads to better access to finance. They found that firms with better CSR performance face significantly lower capital constraints, furthermore, the interpretation of CSR, deeply affected by culture norms. According to Gjølberg (2009), cultural norms when combined with ongoing national political processes lead to a highly transformed concept of CSR.

Based on the above literature review, four hypotheses are developed to help understand how STG implements CSR:

$\mathrm{H}_{1}$ : Managers of STG perceive that the CSR concept is part of the company's strategic plan and given high commitment from top managers;

$\mathrm{H}_{2}$ : Managers of STG know that there is a direct relationship among implementation of CSR programs, profitability, marketing of product, and customer loyalty;

$\mathrm{H}_{3}$ : Implementation of CSR programs came in response to internal pressure more than external pressure;

$\mathrm{H}_{4}$ : Environment protection is given high concern and awareness in the STG's CSR programs.

\section{Telecommunication Industry in Sudan}

The greatest contribution to Sudanese economy comes from the telecommunication sector, which has seen very impressive development and attracted foreign investors (Abdulla Ali, 2007).

Table 3 illustrates the historical development and progress of the telecommunication sector in Sudan.

Table 3

Telecommunication Progress in Sudan

\begin{tabular}{|l|l|}
\hline 1859 & Telecommunication introduced in Sudan (first telegraph link between Cairo and Sawaken) \\
\hline $1871-1873$ & Telegraph line reached Khartoum (small unit for post \& telegraph) \\
\hline $1892-1903$ & First telephone exchange in Sudan (Eldaba \& Khartoum) \\
\hline $1910-1971$ & The service was run by a government body known as posts \& telegraphs \\
\hline $1971-1978$ & Telecommunication was separated from the postal service and run as a government department \\
\hline $1978-1993$ & Sudan Telecommunications Public Corp (STPC) \\
\hline $1993-1994$ & Privatization of telecommunication sector \\
\hline $1994-2001$ & National telecommunication council \\
\hline 2001 & National Telecomm. Corporation (NTC) formed under Telecommunication Act 2001 \\
\hline 1994 & Sudan Telecom Co. (SUDATEL) started as an operator and service provider \\
\hline 1997 & License issued to a cellular service provider, Sudanese Mobile Telephone Co. (MOBITEL) \\
\hline 1997 & First ISP, Sudanese Internet Service Co. (Sudanet) \\
\hline 2001 & First pre-paid service, Ashraaf International (Ashraaf com) \\
\hline 2003 & License issued to the second mobile operator (Areeba) \\
\hline 2005 & License issued to the second fixed operator (Canar) \\
\hline 2006 & Sudatel launched its 3G-UMTS Network (Sudani) \\
\hline
\end{tabular}

Source: Retrieved from www.ntc.gov.sd.ph/info_report_annual_report.php.

\section{Current Status}

In 2012, the total investment in the telecommunication sector in Sudan accounted for $\$ 6$ billion, with a growth rate of $70 \%$ when compared with the $2 \%$ in 1995 (Retrieved from www.ntc.gov.sd. ph/info_report_annual_report.php). 
Over the past two decades, the number of telecommunication companies in Sudan increased from one to five: three delivering mobile services (Zain, Sudani, and MTN) and the other two managing and delivering fixed network services (Thabit and Canar).

Table 4

Number of Subscribers in Sudanese Telecommunication Companies and Internet 2012-2013 (in Thousands)

\begin{tabular}{llll}
\hline Company name & 2012 & $2013 *$ & Growth rate \\
\hline Sudatel Telecommunication Group (STG) & 7,298 & 7,294 & $(0.1)$ \\
Thabit Fixed Line Company & 79 & 95 & 20.7 \\
Sudani Mobile Company & 7219 & 7199 & $(0.3)$ \\
Zain & 12,557 & 11,731 & $(6.6)$ \\
MTN & 7,905 & 8,739 & 10.6 \\
Canar & 316 & 324 & 2.6 \\
Broadband Internet subscribers & 415 & 488 & 17.7 \\
Normal Internet subscribers & 28 & 28 & 0.0 \\
\hline
\end{tabular}

Note. *Primary data. Source: Retrieved from www.cbos.gov.sd/en/sites/default/files/annual_report_e-2013-pdf.

STG comprises two companies: Thabit Fixed Line Company and Sudani Mobile Company. Sudatel's subscribers fell to 7,294 million in 2013 from 7,298 million in 2012, at a rate of $0.1 \%$. An increase of $20.7 \%$ is for fixed lines and a decline of $0.3 \%$ is for mobile services. MTN's number of subscribers increased to 8,739 million in 2013, from 7,905 million in 2012, at a rate of 10.6\%; while Canar Company's subscribers increased from 316,000 to 324,000 in 2013 at a rate of $2.6 \%$. The broadband Internet subscribers rose from 415,000 to 488,000 in 2013 at a rate of $17.7 \%$; while the number of subscribers to normal Internet services remained steady in 2012 and 2013.

\section{Sudatel Telecom Group}

STG was established in 1993 after the privatization of STPC. Since its foundation, STG has grown steadily from local to regional markets, setting a good example for the privatization policy. STG is the bridge for telecommunication movement among the Arab world, Africa, and the rest of the world (Retrieved from www.sudatel.sd/en/Sudatel/section/?Topic=5182).

STG offers various telecom services and keeps its competitive edge with other companies. STG's main services include provision of mobile services, fixed-line services, as well as carrier and wholesale services. The company provides services at 2G, 3G, and NGN technology levels. STG services are expanded into many cities and rural areas, achieving the widest coverage and most significant presence.

\section{STG's CSR}

Sudatel CSR philosophy is based on and influenced by the national culture (Islam), which states that Sudatel's concept of social responsibility is based upon a true Islamic vision — an integrated system for social rights defined by Islam for all people in wealth and money. A considerable amount of studies agreed on this mean that national culture does have an effect on how CSR plans are set up and what they contain (Ida, 2013; Sabir, Faroogi, \& Shahnawaz, 2015; Liang, Marquis, Renneboog, \& Sun, 2014; Orij, 2010; Lunenberg, 2014). Furthermore, the company added that "Sudatel has considerably contributed in realizing sustainable development, improved the living standards of its workers and their families as well as local communities and the society as a whole, and preserved the environment and has taken full commitment of communal service as a strategic option" (Retrieved from www.sudatel.sd/en/Sudatel/section/?Topic=5182). 


\section{Data and Methodology}

The sample taken to examine the hypotheses of this paper consists of 73 managers from STG. Survey questionnaires reflecting all research areas have been used as an instrument for collecting data using a five-point Likert scale, ranging from strongly agree, agree, neutral, disagree, to strongly disagree to determine the response of the participant.

The first part of the questionnaire covers personal information, which includes four questions about gender, age, educational qualification, and managerial level. While the second part includes 29 questions regarding the opinion of the participant on CSR, grouped into six categories: The first category is designed to measure whether CSR exists in the company's concepts, strategies, philosophies, values, and commitment; the second category of this part concerns about the CSR implementation; the third category is the awareness and satisfaction of the company's managers toward CSR programs; the fourth category concerns the relationship among CSR implementation and customer loyalty, profitability, shareholders dividend, and product marketing; the fifth category examines the environmental dimension of CSR; and the sixth category regards the implications of CSR for human resource issues, such as job design, development of skills and talents, and justice and fairness.

The third part of questionnaire concerns ordering the topics of internal and external drivers behind CSR according to the participant's views, and ordering the main CSR programs according to their importance, as well as the (SGT) awareness and preservation of the environment. The participant scores on a five-point scale with " 5 " being "very low" and " 1 " very high.

The fourth part of the questionnaire is opened for the participant's suggestion on SGT's CSR implementation.

\section{Data Analysis}

A descriptive statistical method, such as SPSS, was used to analyze the data collected. To test the hypothesis Chi-square test was performed.

For examining whether CSR programs are featured in the company's culture strategic plans or whether the SGT management highly committed to CSR programs, hypotheses were evaluated.

Hundred questionnaires were distributed and 73 have been returned with $73 \%$ response rate.

\section{Study Reliability}

As a measure of internal consistency, Cronbach's alpha is used as a statistical tool to assess how reliably survey or test items that are designed to measure the same construct actually do so. It is widely employed, because it uses a great deal of information about the items in questions and their correlations (Alan, 1995). The reliability (Cronbach's alpha) of this instrument was acceptable at 0.85 based on the standardized item at 0.90 and the number of items at 49 indicates that the measuring instruments are capable of consistently measuring the same construct (Table 5).

Table 5

Reliability Statistics

\begin{tabular}{lll}
\hline Cronbach's alpha & Cronbach's alpha based on standardized items & No. of items \\
\hline 0.851 & 0.897 & 49 \\
\hline
\end{tabular}

Table 6 shows that 52 of the participants $(71.2 \%)$ are male, while 21 are female $(28.8 \%)$. The majority of the participants were of the age group 41-50 (65.7\%). Eleven participants were over 50 years of age (15\%) and only 12 participants were in the $20-31$ years category $(16.4 \%)$. 
As can be seen in Table 6, the large majority of participants $(37,50.7 \%)$ had a bachelor degree, 12 had higher diploma (16.4\%), while the master degree participants were $15(20.5 \%)$, and higher school $9(12.3 \%)$.

Table 6 also shows that 42 of the participants (57.5\%) held the title of first-line manager and among others only five $(6.8 \%)$ were top managers and $26(35.6 \%)$ were middle managers; the previous information also was illustrated in Figure 1.

Table 6

\section{Descriptive Statistics of Data Collected}

\begin{tabular}{lll}
\hline & Frequency & Percent \\
\hline Gender & & \\
\hline Male & 52 & 71.2 \\
Female & 21 & 28.8 \\
\hline Age & & \\
\hline $20-31$ & 12 & 16.4 \\
$32-40$ & 22 & 30.1 \\
$41-50$ & 26 & 35.6 \\
Above 50 & 11 & 15.1 \\
\hline Education & & \\
\hline High school & 9 & 12.3 \\
Bachelor & 37 & 50.7 \\
Higher diploma & 12 & 16.4 \\
Master's & 15 & 20.5 \\
\hline Management level & & \\
\hline Top management & 5 & 6.8 \\
Middle management & 26 & 35.6 \\
First line management & 42 & 57.5 \\
\hline
\end{tabular}
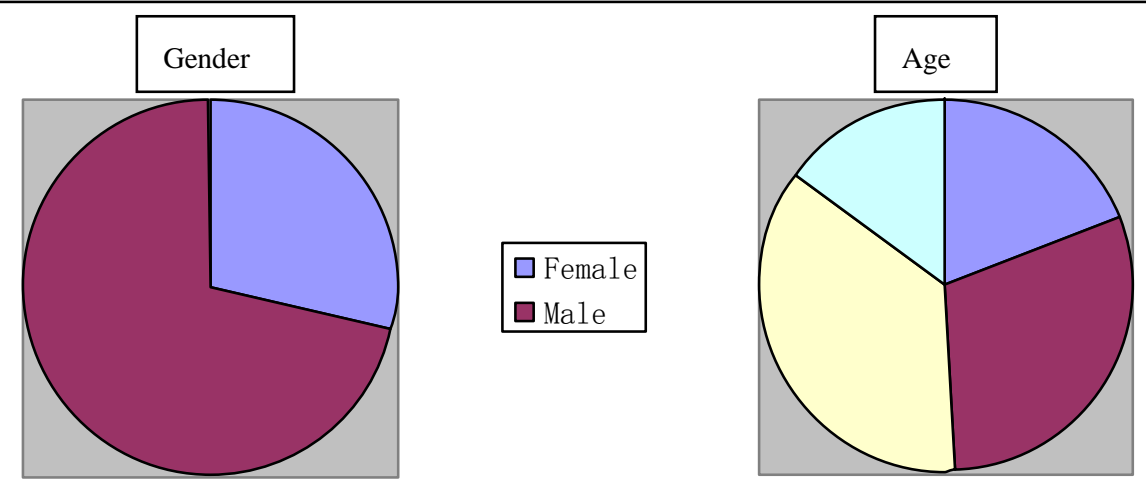

$\square 20-31$

$\square 32-40$

$\square 41-50$

$\square$ More Than 50
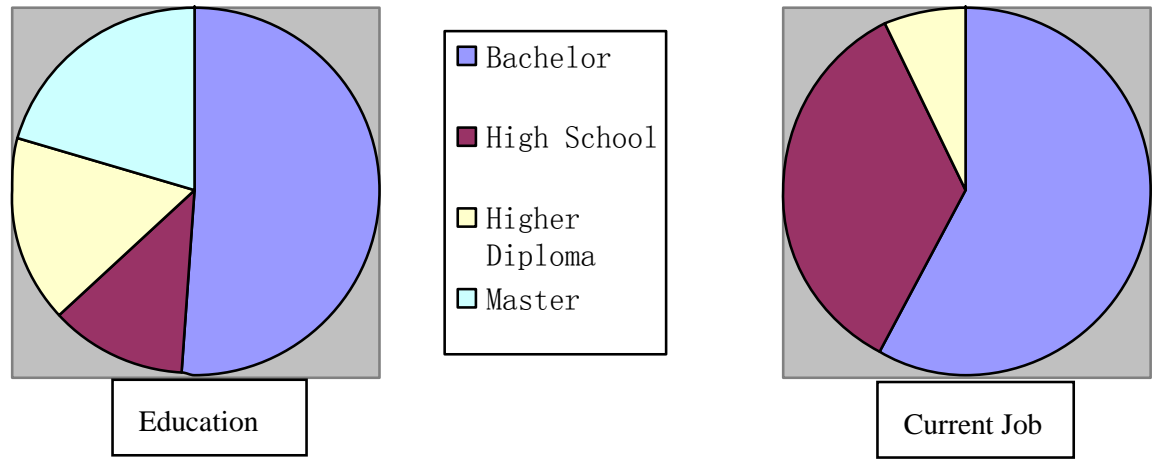

First Line

Magament

$\square$ Middle

Management

$\square$ Top

Management

Figure 1. Descriptive statistics of data collected. 
Chi-square test was used to measure the relationship between the STG and their perception toward the company's CSR practice. The results are shown in Table 7.

Table 7

The Relationship Between STG and Their Perception Toward the Company's CSR Practice

\begin{tabular}{|c|c|c|c|}
\hline & Gender & Educational level & Job level \\
\hline Question & \multicolumn{3}{|c|}{ Chi-square test $p$-value } \\
\hline Q 2.1 & 0.708 & 0.317 & 0.038 \\
\hline Q 2.2 & 0.195 & 0.633 & 0.339 \\
\hline Q 2.3 & 0.447 & 0.372 & 0.190 \\
\hline Q 2.4 & 0.122 & 0.271 & 0.001 \\
\hline Q 2.5 & 6.220 & 0.419 & 0.036 \\
\hline Q 2.6 & 0.592 & 0.177 & 0.271 \\
\hline Q 2.7 & 0.665 & 0.732 & 0.050 \\
\hline Q 2.8 & 0.740 & 0.341 & 0.014 \\
\hline Q 2.9 & 0.431 & 0.888 & 0.047 \\
\hline Q 2.10 & 0.064 & 0.605 & 0.423 \\
\hline Q 2.11 & 0.466 & 0.369 & 0.887 \\
\hline Q 2.12 & 0.740 & 0.753 & 0.078 \\
\hline Q 2.13 & 0.473 & 0.360 & 0.029 \\
\hline Q 2.14 & 0.228 & 0.263 & 0.069 \\
\hline Q 2.15 & 0.172 & 0.470 & 0.235 \\
\hline Q 2.16 & 0.133 & 0.645 & 0.033 \\
\hline Q 2.17 & 0.393 & 0.389 & 0.626 \\
\hline Q 2.18 & 0.684 & 0.607 & 0.308 \\
\hline Q 2.19 & 0.308 & 0.027 & 0.254 \\
\hline Q 2.20 & 0.435 & 0.753 & 0.405 \\
\hline Q 2.21 & 0.128 & 0.165 & 0.223 \\
\hline Q 2.22 & 0.294 & 0.846 & 0.285 \\
\hline Q 2.23 & 0.005 & 0.328 & 0.004 \\
\hline Q 2.24 & 0.325 & 0.749 & 0.185 \\
\hline Q 2.25 & 0.284 & 0.523 & 0.939 \\
\hline Q 2.26 & 0.211 & 0.421 & 0.890 \\
\hline Q 2.27 & 0.227 & 0.362 & 0.848 \\
\hline Q 2.28 & 0.090 & 0.669 & 0.496 \\
\hline Q 2.29 & 0.923 & 0.482 & 0.772 \\
\hline Q 3.1.1 & 0.195 & 0.093 & 0.000 \\
\hline Q 3.1.2 & 0.772 & 0.498 & 0.529 \\
\hline Q 3.1.3 & 0.120 & 0.252 & 0.000 \\
\hline Q 3.1.4 & 0.058 & 0.890 & 0.022 \\
\hline Q 3.1.5 & 0.219 & 0.700 & 0.203 \\
\hline Q 3.2.1 & 0.181 & 0.012 & 0.001 \\
\hline Q 3.2.2 & 0.210 & 0.291 & 0.689 \\
\hline Q 3.2.3 & 0.080 & 0.170 & 0.000 \\
\hline Q 3.2.4 & 0.591 & 0.580 & 0.000 \\
\hline Q 3.2.5 & 0.363 & 0.195 & 0.000 \\
\hline Q 3.3.1 & 0.093 & 0.319 & 0.609 \\
\hline Q 3.3.2 & 0.659 & 0.624 & 0.351 \\
\hline Q 3.3.3 & 0.097 & 0.784 & 0.396 \\
\hline Q 3.3.4 & 0.454 & 0.580 & 0.765 \\
\hline Q 3.3 .5 & 0.465 & 0.409 & 0.553 \\
\hline
\end{tabular}


The results show that there was no significant difference among STG mangers gender, age, educational level, and the company's CSR practice; for the management level, the result shows that there was significant difference between manager's level and their perception toward the company's (CSR) practice.

Respondents' views as to whether the concept of CSR programs are featured in the company's culture and strategic plans or whether the managements of the company are highly committed to CSR programs are shown in Table 8.

Table 8

The Views of STG Managers on CSR

\begin{tabular}{|c|c|c|c|c|c|c|}
\hline Question & $\begin{array}{l}\text { Strongly } \\
\text { agree } \\
(\%)\end{array}$ & $\begin{array}{l}\text { Agree } \\
(\%)\end{array}$ & $\begin{array}{l}\text { Neutral } \\
(\%)\end{array}$ & $\begin{array}{l}\text { Disagree } \\
(\%)\end{array}$ & $\begin{array}{l}\text { Strongly } \\
\text { disagree } \\
(\%)\end{array}$ & $\begin{array}{l}\text { Total } \\
(\%)\end{array}$ \\
\hline Corporate social responsibility (CSR) is part of the company's strategic plan. & 30 & 53 & 6 & 11 & 0 & 100 \\
\hline $\begin{array}{l}\text { There is a higher comment from top management toward implementation of } \\
\text { CSR concepts. }\end{array}$ & 51 & 32 & 6 & 12 & 0 & 100 \\
\hline $\begin{array}{l}\text { CSR is considered as one of the values, concepts, philosophy, and culture of } \\
\text { the company. }\end{array}$ & 47 & 37 & 4 & 12 & 0 & 100 \\
\hline Implementation of CSR programs drives as a response to internal pressure. & 19 & 9 & 8 & 29 & 35 & 100 \\
\hline Implementation of CSR was in response to external pressure. & 11 & 18 & 11 & 22 & 38 & 100 \\
\hline Implementation of CSR programs is in accordance with the strategic plan. & 47 & 34 & 4 & 14 & 1 & 100 \\
\hline CSR programs are just donations from time to time. & 15 & 30 & 6 & 16 & 33 & 100 \\
\hline CSR programs take large amount from company budget. & 43 & 38 & 1 & 16 & 1 & 100 \\
\hline $\begin{array}{l}\text { The company's activities and programs are designed and implemented in a } \\
\text { manner which takes into account CSR. }\end{array}$ & 45 & 36 & 3 & 14 & 3 & 100 \\
\hline I have awareness on the concepts of CSR. & 48 & 37 & 10 & 4 & 1 & 100 \\
\hline Company encourages employees to volunteers for community services issues. & 26 & 49 & 6 & 16 & 3 & 100 \\
\hline $\begin{array}{l}\text { I think that there is a direct relation between implementation of CSR programs } \\
\text { and profitability. }\end{array}$ & 43 & 41 & 3 & 14 & 0 & 100 \\
\hline I think that implementation of CSR increases consumer loyalty. & 49 & 36 & 15 & 0 & 0 & 100 \\
\hline $\begin{array}{l}\text { I think that one of the company's social responsibility is to provide safe, } \\
\text { healthy, and environmentally friendly products and services. }\end{array}$ & 38 & 50 & 4 & 7 & 1 & 100 \\
\hline I think that the benefits of CSR are greater than cost. & 49 & 43 & 1 & 7 & 0 & 100 \\
\hline I think that CSR does not conflict with increasing the profit for share holders. & 48 & 45 & 7 & 0 & 0 & 100 \\
\hline $\begin{array}{l}\text { Company believes that the CSR is the management approach that combines } \\
\text { together economic, social, and environmental priorities. }\end{array}$ & 38 & 41 & 4 & 15 & 1 & 100 \\
\hline CSR concepts extended beyond the charity concepts. & 41 & 39 & 4 & 12 & 4 & 100 \\
\hline I think that I'm satisfied with the company's CSR performance. & 56 & 26 & 18 & 0 & 0 & 100 \\
\hline Company has a clear annual plan to implement CSR programs. & 51 & 34 & 4 & 11 & 0 & 100 \\
\hline CSR supports the company in the marketing of products. & 49 & 45 & 3 & 3 & 0 & 100 \\
\hline Company has a clear regulation for safety and health in the work place. & 19 & 51 & 15 & 11 & 4 & 100 \\
\hline Company has adverse environmental activities. & 11 & 38 & 12 & 21 & 18 & 100 \\
\hline $\begin{array}{l}\text { Company works to reduce the impact on the environment as much as } \\
\text { possible. }\end{array}$ & 19 & 49 & 14 & 14 & 4 & 100 \\
\hline Company helps employees to develop their talents and abilities. & 19 & 56 & 8 & 15 & 1 & 100 \\
\hline Company provides learning and rewards good work. & 21 & 53 & 8 & 16 & 1 & 100 \\
\hline $\begin{array}{l}\text { Company provides equal opportunities in the recruitment and development } \\
\text { with non-discrimination for any reason. }\end{array}$ & 19 & 53 & 7 & 19 & 1 & 100 \\
\hline Job design is more attractive. & 18 & 56 & 7 & 18 & 1 & 100 \\
\hline Job design is routine, boring, and more specialized. & 6 & 25 & 7 & 30 & 33 & 100 \\
\hline
\end{tabular}


Table 9

Participant's Ordering for Some CSR Dimensions According to Their Importance

\begin{tabular}{|c|c|c|c|c|c|c|}
\hline & $\begin{array}{l}\text { Critical } \\
(\%)\end{array}$ & $\begin{array}{l}\text { Very } \\
\text { important } \\
(\%)\end{array}$ & Important & $\begin{array}{l}\text { Slightly } \\
\text { important } \\
(\%)\end{array}$ & $\begin{array}{l}\text { Unimportant } \\
(\%)\end{array}$ & $\begin{array}{l}\text { Final } \\
\text { classification }(\%)\end{array}$ \\
\hline \multicolumn{7}{|c|}{ Company's internal pressure which is considered as the drive to implement CSR programs } \\
\hline Company culture, philosophy, and values & 48 & 19 & 5 & 7 & 21 & Critical \\
\hline Improve the reputation and image of the company & 0 & 22 & 52 & 25 & 1 & Important \\
\hline Company's strategic plan & 26 & 34 & 30 & 4 & 5 & Very important \\
\hline Employees pressure & 11 & 15 & 10 & 47 & 18 & Slightly important \\
\hline To increase company sales & 15 & 7 & 3 & 21 & 55 & Unimportant \\
\hline \multicolumn{7}{|c|}{ Company's external pressure which is considered as the drive to implement CSR programs } \\
\hline Non-company organization & 5 & 10 & 25 & 38 & 22 & Slightly important \\
\hline Rules and regulations & 0 & 14 & 52 & 29 & 5 & Important \\
\hline Customers and consumers & 29 & 45 & 11 & 12 & 3 & Very important \\
\hline Community service & 47 & 27 & 1 & 11 & 14 & Critical \\
\hline Governmental and political pressure & 19 & 4 & 10 & 10 & 58 & Unimportant \\
\hline \multicolumn{7}{|c|}{ Order of CSR programs' implements by the company according to their importance } \\
\hline Provide high-quality service & 5 & 1 & 15 & 53 & 25 & Slightly important \\
\hline Education service & 0 & 68 & 18 & 14 & 0 & Very important \\
\hline Health service & 71 & 4 & 16 & 1 & 7 & Critical \\
\hline Sport sponsorship & 21 & 15 & 49 & 12 & 3 & Important \\
\hline Dissemination of technological awareness & 4 & 11 & 1 & 18 & 66 & Unimportant \\
\hline
\end{tabular}

The majority of the respondents (83\%) agreed that CSR is part of the company's strategic plan, there is a higher comment from top management toward implementation of CSR concepts, and CSR is considered as one of the values, concepts, philosophy, and culture of the company, which proves the hypothesis of managers of SGT that the CSR concept is part of a company's strategic plan and given high commitment from top managers.

Eighty-four percent of participants agreed that the implementation of CSR programs drives as a response to internal pressure, while only $28 \%$ of participants agreed that the implementation of CSR was in response to external pressure.

Eighty-five percent of managers of (SGT) knew that there is a direct relationship between implementation of CSR programs and profitability; 94\% of them also agreed that there is a relationship between CSR and marketing of products, while $85 \%$ agreed that there is a relationship between CSR and customer loyalty.

With regard to whether the environment protection is given high concern and awareness in the SGT's CSR programs, $88 \%$ of the participants agreed that one of the company's social responsibilities is providing environmentally friendly products and services.

In the section of the implications of CSR for human resource issues, such as job design, development of skills and talents, justice and fairness, the majority of participants thought that the company gives high concern to the human resource issues with some variation in some issues as follows:

- Seventy-five percent agreed that the company helps employees to develop their talents and abilities;

- Seventy-four percent agreed that the company provides learning and rewards good work;

- Seventy-two percent agreed that company provides equal opportunities in the recruitment, development with non-discrimination for any reason;

- Seventy-four percent agreed that job design is more attractive; 
- Sixty-six percent disagreed that job design is routine, boring, and more specialized.

The third part of questionnaire is used to know the opinion of the participants on some dimensions of CSR, such as internal and external drivers behind CSR, the main CSR programs adapted by the company, as well as the SGT awareness of and preservation of the environment. The participants score on a five-point scale with " 5 " being "very low" and "1" very high.

According to the participants' views, the order of the company's internal pressure which is considered as the drive to implement CSR programs comes as follows:

(1) first: company culture, philosophy, and values;

(2) second: company strategic plan;

(3) third: improve the reputation and image of the company;

(4) fourth: employees pressure;

(5) fifth: to increase company sales.

While the company's external pressure, which is considered as the drive to implement CSR programs, is ordered as follows:

(1) community service;

(2) customers and consumers;

(3) rules and regulations;

(4) non-company organization;

(5) governmental and political pressure.

The participants' ordering of CSR program implements by the company according to their importance is as follows:

(1) first: health service;

(2) second: education service;

(3) third: sport sponsorship;

(4) fourth: provide high-quality service;

(5) fifth: dissemination of technological awareness.

Table 10 shows the response of the participants to "if there is any awareness of interest in preserving the environment by the company as one of CSR programs?"

Table 10

Awareness of Interest in Preserving the Environment by the Company as One of CSR Programs

\begin{tabular}{llllll}
\hline & & Frequency & Percent & Valid percent & Cumulative percent \\
\hline \multirow{4}{*}{ Valid } & Yes & 56 & 76.7 & 76.7 & 76.7 \\
& No & 17 & 23.3 & 23.3 & 100.0 \\
& Total & 73 & 100.0 & 100.0 & \\
\hline
\end{tabular}

Fifty-six participants (76.7\%) answered that the company has awareness of interest in preserving the environment by the company as one of the CSR programs, while 17 participants (23.3\%) think that the company does not.

Table 11 shows the order of the company's environmental preservation programs according to their importance.

According to the participants' views, the order of the company's environmental preservation programs according to their importance is as follows: 
(1) first: reduce pollution;

(2) second: reduce the emission of gases and radiation;

(3) third: reduce losses and waste;

(4) fourth: reduce the amount of resources used;

(5) fifth: reduce the amount of resources used.

Table 11

If Yes, Order the Following Topics According to Their Importance From (1) to (5) as a Means to Preserve the Environment

\begin{tabular}{|c|c|c|c|c|c|c|}
\hline & Critical (\%) & $\begin{array}{l}\text { Very } \\
\text { important } \\
(\%)\end{array}$ & $\begin{array}{l}\text { Important } \\
(\%)\end{array}$ & $\begin{array}{l}\text { Slightly } \\
\text { important } \\
(\%)\end{array}$ & $\begin{array}{l}\text { Unimportant } \\
(\%)\end{array}$ & $\begin{array}{l}\text { Final } \\
\text { classification }\end{array}$ \\
\hline Reduce pollution & 86 & 2 & 0 & 0 & 13 & Critical \\
\hline Reduce the amount of resources used & 4 & 16 & 9 & 55 & 16 & Slightly important \\
\hline Reduce losses and waste & 2 & 9 & 68 & 21 & 0 & Important \\
\hline Reduce material & 0 & 11 & 13 & 18 & 59 & Unimportant \\
\hline Reduce the emission of gases and radiation & & 63 & 11 & 5 & 13 & Very important \\
\hline
\end{tabular}

\section{Conclusions}

The main aim of this paper is to examine the strategic importance of CSR of SGT. Three of the hypotheses designed were accepted, indicating that there is no significant importance of CSR to the managers of SGT, when it comes to the performance of SGT, there was positive significant relationship between CSR and profit, and number of customers and subscribers to the company.

The mangers of STG perceived that the CSR concept is part of the company's strategic plan and given high commitment from the top management, and they know that there is a direct relationship among implementation of CSR programs and profitability, marketing of products, and customer loyalty.

Mangers of STG agreed that the implementation of CSR programs came in response to internal pressure more than external pressure. The hypothesis of environment protection given high concern and awareness in the SGT's CSR programs is rejected, since there are significant differences based on the mangers' job level.

The study was conducted with only one company in the STG. The sector includes four other companies Zain, MTN, Canar, and Thabit. A limitation might arise because of potential single source bias, thus limiting the generalization to other companies in the sector.

\section{References}

Abdulla Ali, A. (2007). Sudan and the telecommunication industry. Retrieved from www.sudantribune.com.Sudan/spip?article22959

Alan, B. (1995). Research methods and organization studies. London: Routledge.

Alexander, D. (2008). How corporate social responsibility is defined: An analysis of 37 definitions. Corporate Social Responsibility and Environmental Management, 15, 1-13.

Beiting, C., Loannou, L., \& Serafeim, G. (2014). Corporate social responsibility and access to finance. Strategic Management Journal, 35, 1-23.

Breitbarth, T., Hovemann, G., \& Walzel, S. (2011). Scurry strategy goals: Measuring corporate social responsibility in professional European football. Thunderbird International Business Review, 53(6), 721-737.

Carmen, V. (2005). Corporate social responsibility and corporate citizenship: Towards corporate accountability. Business and Society Review UK, 110(2), 191-212. 
De Jongh, D. (2009). Corporate responsibility: Becoming a corporate citizen leadership. Management Today, 25(3), 16-19.

Dobers, P., \& Halme, M. (2009). Editorial corporate social responsibility and developing countries. Corporate Social Responsibility and Environmental Management, 16, 237-249.

Drucker, P. F. (1984). Converting social problems into business opportunities: The new meaning of corporate social responsibility. California Management Review, 26(2), 53-63.

Friedman, M. (1970). The social responsibility of business is to increase its profits. Retrieved from http://www.umich.edu/ thecore/doc/Friedman.pdf

Gjølberg, M. (2009). Measuring the immeasurable? Conserving an index of CSR practices and CSR performance in 20 countries. Scandinavian Journal of Management, 25(1), 10-22.

Globerman, S. (2011). The social responsibility of managers: Reassessing and integrating divers respective. BASR Business and Society Review, 116(4), 509-532.

Herrmann, K. K. (2004). Corporate social responsibility and sustainable development: The European Union initiative as a case study. Indian Journal of Global Legal Studies, 11, 205-232.

Ida, O. (2013). The influence of national culture in CSR-reporting. A cross-cultural study of Denmark and France (Master thesis, Business and Development Studies Copenhagen Business School).

Jamai, D., \& Sidani, Y. (2008). Classical vs. modern management CSR perspectives: Insight from Lebanese context and cross-cultural implications. Business and Society Review, 113(3), 329-346.

Kevin, L., \& Jean, F. T. (2013). Does corporate social responsibility contribute to human development in developing countries, evidence from Nigeria. Journal of Human Development and Capabilities, 14(2), 241-265.

Kloppers, H. (2013). Creating a CSR —Enabling environment: The role of government. SA Public Law, 28(1), 121-145.

Lee, K., \& Kim, H. (2014). Corporate social responsibility (CSR) practice and implantation within the institutional context: The case of the Public of Korea. Gewerbestrasse: Springer International Publishing.

Liang, H., Marquis, C., Renneboog, L. D. R., \& Sun, L. S. (2014). Speaking of corporate social responsibility. Retrieved from https://pure.uvt.nl/portal/en/publications/speaking-of-corporate-social-responsibility(1b8f9b47-56b4-42a0-87de-a2ae198812 92).html

Luken, R. E. (2006). Where is developing country industry in sustainable development planning? Sustainable Development, 14(1), 46-61.

Lunenberg, K. (2014). The influence of national culture on the implementation of corporate social responsibility-students' legitimacy in universities (Master thesis, University of Twente).

Mc Williams, A., \& Siegel, D. (2001). Corporate social responsibility: Q theory of the firm perspective. The Academy of Management Review, 20(1), 166-179.

Mia, M. R., \& Nakib, M. N. (2013). Corporate social responsibility implementation in the EU and USA: The trend and the way forward. In J. O. Okpara and S. O. Idowu (Eds.), Corporate social responsibility: Challenges, opportunities and strategies for 21 st century leaders (pp. 181-197). Heidelberg: Springer Berlin.

Muller, A. (2006). Global versus local CSR strategies. European Management Journal, 24(2-3), 189-198.

Natural Telecommunication Corporation. (2012). Natural telecommunication corporation annual report. Retrieved from www.ntc.gov.sd.ph/info_report_annual_report.php

Orij, R. (2010). Corporate social disclosures in the context of national cultures and stakeholders theory. Accounting, Auditing, \& Accountability Journal, 23(7), 868-889.

Patsy, P. (2012). Exploring the influence of national culture contest on CSR implementation. Journal of Fashion Marketing and Management, 16(2), 141-160.

Sabir, R. I., Faroogi, A. R., \& Shahnawaz, M. (2015). Impact of corporate social responsibility on socio-economic development in Pakistan. Scholedge International Journal of Management \& Development, 2(2), 1-8.

Sudan Central Bank. (2013). Sudan central bank 53rd annual report, 2013 . Retrieved from www.cbos.gov.sd/en/sites/default/files/annual_report_e-2013-pdf

Sudatel Telecom Group. (2014). Sudatel Telecom Group annual report, 2014 . Retrieved from www.sudatel.sd/en/Sudatel/section/?Topic $=5182$

Tiago, M., \& Garrido-Morgado, A. (2012). Corporate reputation: A combination of social responsibility and industry. Corporate Social Responsibility and Environmental Management, 19, 11-31.

Van Marrewijk, M. (2003). Concepts and definitions of CSR and corporate sustainability: Between agency and communication. Journal of Business Ethics, 44, 95-105. 